\title{
Science teacher identity and eco-transformation of science education: comparing Western modernism with Confucianism and reflexive Bildung
}

\author{
Jesper Sjöström ${ }^{1}$ (ID
}

Received: 4 June 2016/Accepted: 7 December 2016/Published online: 13 October 2017

(C) The Author(s) 2017. This article is an open access publication

\begin{abstract}
This forum article contributes to the understanding of how science teachers' identity is related to their worldviews, cultural values and educational philosophies, and to eco-transformation of science education. Special focus is put on 'reform-minded' science teachers. The starting point is the paper Science education reform in Confucian learning cultures: teachers' perspectives on policy and practice in Taiwan by Ying-Syuan Huang and Anila Asghar. It highlights several factors that can explain the difficulties of implementing "new pedagogy" in science education. One important factor is Confucian values and traditions, which seem to both hinder and support the science teachers' implementation of inquiry-based and learner-centered approaches. In this article Confucianism is compared with other learning cultures and also discussed in relation to different worldviews and educational philosophies in science education. Just like for the central/north European educational tradition called Bildung, there are various interpretations of Confucianism. However, both have subcultures (e.g. reflexive Bildung and Neo-Confucianism) with similarities that are highlighted in this article. If an "old pedagogy" in science education is related to essentialism, rationalist-objectivist focus, and a hierarchical configuration, the so called "new pedagogy" is often related to progressivism, modernism, utilitarianism, and a professional configuration. Reflexive Bildung problematizes the values associated with such a "new pedagogy" and can be described with labels such as post-positivism, reconstructionism and problematizing/critical configurations. Different educational approaches in science education, and corresponding eco-identities, are commented on in relation to transformation of educational practice.
\end{abstract}

Lead editor: Anita Hussénius.

This review essay addresses issues raised in Ying-Syuan Huang and Anila Asghar's article, 'Science education reform in Confucian learning cultures: teachers' perspectives on policy and practice in Taiwan'. doi:10.1007/s11422-016-9762-4.

Jesper Sjöström

jesper.sjostrom@mah.se

1 Department of Science-Environment-Society, Faculty of Education and Society, Malmö

University, 20506 Malmö, Sweden 
Keywords Cultural values · Worldviews · Reform-orientation · Reconstructionism · Philosophy of science education

This forum article reflects on and gives perspective to the article Science education reform in Confucian learning cultures: teachers' perspectives on policy and practice in Taiwan by Ying-Syuan Huang and Anila Asghar (this issue). Their article deals with identity construction based on a negotiation between factors such as traditions, educational policy, teachers' own educational philosophy and parents' views. The implementation of change initiatives is dependent on the teachers' understanding of reform policies and their cultural values, epistemological beliefs and pedagogical commitments. The article especially deals with the connections to the ideas of Confucianism, which are important in East Asia, and show that "science teachers' perspectives on Confucian learning traditions play a key role in supporting or obstructing their pedagogical commitments to inquiry-based and learnercentered approaches" (p. 1 ahead of print).

In Taiwan, just like in many other countries in the world, there has been a governmentdriven science education transformation movement (so called "new pedagogy"- constructivist learning approaches) during the last two decades. It has been driven by the goal "to develop essential scientific literacy competencies, such as analytical reasoning, critical thinking, conceptual understanding and problem solving skills" (p. 3 a.o.p.) among the learners and from a societal point of view to promote social and economic development. However, the authors indicate that transformations are not always easy to achieve.

The article mentions several factors that can explain the difficulties of implementing such a "new pedagogy": it is too complex, the teachers are not prepared for it, they feel that they lose control and that they don't have sufficient experience to facilitate classroom discussions, it is not regarded as compatible with traditional values and with existing beliefs about teaching and learning, parents are worried about bad results on national standardized examinations, and there is lack of professional support. Other issues mentioned are the lack of connection between education policies and real classroom settings as well as inadequate resources and time.

In the study Confucian traditions were found both to inhibit independent thinking and creativity and to promote equality and equity in education (Huang and Asghar, this issue). It is interesting that Confucian values and traditions are used with several different meanings, such as courtesy, self-cultivation, respect, discipline, humility, humanity and "harmony in the society". In other words there is a tension between discipline/respect on the one hand and humanity/harmony on the other hand. Many of the teachers thought that "Confucian traditions of self-discipline and respect for authority might constrain learners' autonomy, innovative thinking and free expression in the classroom" (p. 18 a.o.p.), which can limit creativity and scientific development. On the other hand all the teachers interviewed emphasized the importance of Confucian ethics for Taiwanese society at large. Only a few of the interviewed teachers had a clear idea of the positive and negative aspects of Confucianism on science teaching. An exception is Xiao, one of ten teachers in the study; he "found that the philosophy of inquiry-based learning was [...] similar to the Confucian principle of ying cai shi jiao-to teach in accordance with the individual's ability" (p. 21 a.o.p.). He has tried to find a balance between traditional and inquiry-based teaching strategies. 
I think the article by Huang and Asghar raises several issues of broader significance beyond Confucian cultures. It raises questions concerning the identity development of science teachers and its relationship to their worldviews, cultural values and educational philosophies. It also raises questions concerning transformation of educational practice. Below, I will reflect on these issues based on examples also from other cultural contexts than the Confucian. The aim is to contribute to the understanding of how science teachers' identity is connected to cultural values, worldviews (including eco-views), educational philosophies, and transformation of educational practice. Especially I will show how both East and West have ideas/ideologies/values which offer alternatives to the philosophy of traditional (rationalist-objectivist) science education. Special focus is put on identities related to sustainability issues, here called eco-identities, and its implications on the transformation of science education, here called eco-transformation.

\section{Science teacher identity}

Huang and Asghar write that teacher identity "broadly refers to a teacher's self-concept in relation to his or her professional role" (p. 10 a.o.p.). It is socially constructed, dynamic (constantly being formed and reformed), and complex (consisting of several interrelated sub-identities) (Avraamidou 2014). Both identity and the teaching practice are shaped by a number of internal factors (e.g. values, beliefs, emotions) and external circumstances (e.g. professional development, teaching conditions, social surroundings) (Huang and Asghar, this issue).

Erminia Pedretti, Larry Bencze, Jim Hewitt, Lisa Romkey, and Ashifa Jivraj (2008) write: "A teachers' sense of self develops at the intersections of life histories, experiences, and socialization into a professional community. [It] also comes from what a person believes, values and what a person wants to become" (p. 943). In other words the identity is related both to the teachers' views and a sense of belonging as a member of a community. Based on Anthony Giddens, Knud Illeris (2014) defines identity dynamically: "identity has the nature of a 'reflexive project,' implying a constant necessity to change in order to maintain the feeling of being oneself, a balance between stability and flexibility, and between being oneself and changing oneself"' (p. 7-8).

Particularly since the beginning of the new Millennium research has also been conducted about science teacher identity. Recently, Lucy Avraamidou (2014) reviewed current research and recommended future directions. For example she described how researchers in science education quite recently have highlighted the ways teachers' thoughts and approaches are central for implementation of reforms in science education (e.g. the goal of a scientific literacy and inquiry-based science education). Yavuz Saka, Sherry Southerland, Julie Kittleson, and Todd Hutner (2013) call the identity of such teachers 'reform-minded'. However, as April Lynn Luehmann (2007) shows, it is not an easy task to become a reform-minded science teacher. It is a complex process of identity development - a process of forming and reforming oneself. From postmodernist perspectives some researchers have discussed how science teacher identity is influenced by social markers such as gender, age, ethnicity, and religion (e.g. Rivera Maulucci 2013). To these social markers I would like to add that the identity is also dependent on personal ideology in a broad sense. Personal ideology can be said to consist of four parts: (a) epistemology, (b) view of humans, (c) societal view/ideology, and (d) worldview (Sjöström 2006). 
In the book Humanism as a life stance (my translation) the Finnish-Swedish philosopher Georg Henrik von Wright (1978) imbued the four parts with (my interpretation): (a) transdisciplinarity and Bildung (see further below), (b) the creative and curious human, (c) emphasis on solidarity between humans (even unborn), and (d) humans as part of nature (ecocentric approach). Related to this I suggest: (a) a holistic view of the world based on both scientific knowledge and socio-historical-cultural-political perspectives, (b) humanistic view of individuals/subjects, (c) critique of the modern risk society with its injustice and oppression, and (d) a long-term perspective and reverence for nature/the eco-sphere. Together with colleagues, I recently discussed the philosophical foundation and characteristics of science education based on such thoughts. We call it eco-reflexive science education (Sjöström, Eilks and Zuin 2016) and refer to the idea of reflexive Bildung, which I will describe further below (Sjöström and Eilks 2017).

In this article I ask which personal ideology and educational philosophy that characterizes the identity of an 'eco-reform-minded' science teacher, how it is connected to science education practice, and what are the implications for science teacher education and professional development programs? I will discuss this based on a comparison between East Asian Confucianism (and related ideas), Western modernism and also reflexive Bildung. After reading the paper by Huang and Asghar, and later also other papers that I refer to below, I realized that there are some very interesting similarities between Confucian learning cultures and the North European tradition of Bildung.

\section{Different cultural values: comparing Confucianism, modernism and Bildung}

Confucius has been described as one of the most influential thinkers in world history (Reichenbach 2016). Central Confucian vocabularies are for example Way, Virtue, Humanity, Wisdom, Heaven, and Nature (Kato 2016). Learning is central in Confucianism and it is mainly about self-cultivation and ethical knowledge (Hung 2016). It plays an important role in the school cultures of the East Asian countries. Even after the introduction of Western education into these countries, as Duck-Joo Kwak, Morimichi Kato, and Ruyu Hung (2016) write, "the traditional Confucian features of learning retained some of its influence on the educational practice" (p. 1). It is, according to them, about two competing educational-cultural values, i.e. Confucian vs. Western liberalism/modernism.

Western modernism can for example be described with progress optimism and emphasis on knowledge for productivity, or with Sven-Eric Liedman's (1997) words 'hard enlightenment'. He contrasted it with 'soft enlightenment', which emphasizes broad and value-oriented knowledge and which is closely related to Bildung. According to Bernt Gustavsson (2014, p. 109) the very aim "of bildung is to humanize what is often considered to be an instrumental education and society governed by goal-rationality". Similarly, Helmut Fischler (2011, p. 34) writes: "Knowledge is a part of Bildung, but the knowledge is embedded into a holistic view of the personality of an individual".

In a previous paper I problematized-from a Bildung-perspective-the mainstream discourse of chemistry (education) and suggested a complementary discourse, aiming to replace the often too modernistic and reductionistic chemistry discourse with a more sociocritical and holistic one (Sjöström 2007). Such a new discourse would emphasise the role of chemistry as a culture and within a cultural context. I used the term 'discourse of chemistry' to refer to mainstream chemists' philosophical and societal worldviews and 
values (both explicit and implicit). The term can also be described as broad societal and historically based flow of ideas, which dominate the conceptions and practices without the practitioners necessarily being aware of its influence.

Most chemists are progress optimistic and have an approach that assumes that problems in society caused by science can be solved by even more science and technology (Sjöström 2007). This way of thinking is typical of modernism and is sometimes - in its extreme form — called 'scientism'. John Dupré (2001, p. 1) defined scientism as "an exaggerated and often distorted conception of what science can be expected to do or explain for us". More generally Western science can be described with labels such as positivism, objectivism, reductionism, rationalism, and modernism (Sjöström 2007). Many of these characteristics can be explained by the body-mind dualism that has been promulgated in Western civilization since René Descartes (Bernstein 1983). Another dualism typical of Western thoughts is the one between human cultures on one hand and nature on the other hand (Haraway 1989). In contrast to Western dualisms and modernism, most Eastern philosophies are more holistic and system-oriented (Hwang 2013). According to Tamara Savelyeva (2016, p. 15 a.o.p.), Neo-Confucian scholars "view development as an infinite number of possibilities rather than a one-directional way toward social improvement".

Western thinking can, as already indicated above, be described with various orientations of 'enlightenment' (Liedman 1997). Recently, Leonard Tan (2016) discussed the Western so called twenty-first century skills from a Confucian perspective: "Its emphasis on a more holistic, 'all-at-once' approach finds weight in the philosophical tradition of Confucianism" (p. 1236). However, in addition to the similarities between twenty-first century skills and Confucian ideas, there are also differences, such as that "the affective cannot be dissociated from the cognitive" (p. 1236) seen from a Confucian perspective and that if twenty-first century skills are individualistic, the "Confucian portrait of the self $[\ldots]$ is irreducibly social and radically relational" (p. 1238). Tan claims that the Confucian philosophy is not driven by economic concerns, but "by a desire to meliorate the world in which we live". (p. 1241)

However, there are sometimes important differences between the philosophies as such and the traditions seen in practice. According to Duck-Joo Kwak, Morimichi Kato, and Ruyu Hung (2016, p. 2), Eastern and Western traditions of humanistic/liberal learning can be contrasted in the following way: formality vs. free-thinking; conformity vs. independence; and obedience vs. autonomy. This is in line with the tension between discipline/ respect on the one hand and humanity/harmony on the other hand in Confucian thinking/cultures, as was already mentioned in the introduction.

As also indicated above, there are also important similarities between some Eastern and Western ideas. Recently, Roland Reichenbach (2016) compared Neo-Confucian thoughts and ideas with the central/north European notion of Bildung. According to Duck-Joo Kwak, Morimichi Kato, and Ruyu Hung (2016) the Bildung-concept "has always fascinated the Confucian-minded philosophers of education in the East Asian region" (p. 4). But it is important to keep in mind that both Confucian traditions (Reichenbach 2016) and Bildung traditions (Sjöström and Eilks 2017) are not "homogenous body of thought, insights, inspirations, and questions" (Reichenbach 2016, p, 39). In the next section I will more in detail describe the concept of Bildung, which has both objective and subjective aspects and both educational and political dimensions. 


\section{The European notion of Bildung}

Bildung was in its modern form coined in Germany in the late eighteenth century, with roots in both the Enlightenment and Romanticism (Reichenbach 2014). However, its real origins can be traced back to the late Middle Age, when the concept had theological and spiritual connotations, just like Confucianism (Reichenbach 2016). In the 18th century it was mainly connected to humanity and in the end of the 19th century it became understood as a value and commodity (Reichenbach 2016).

Bildung consists of two elements: "autonomous self-formation and reflective and responsible action in (and interaction with) society" (Fellenz 2016, p. 273). For Wolfgang Klafki (2000, p. 87), the terms "self-determination, freedom, emancipation, autonomy, responsibility, reason, and independence" are crucial notions in relation to Bildung. Accordingly the concept shall not only be understood individualistically; it is also characterized by 'humanity' and 'morality' (Fischler 2015). It is about "the individual embedded in a world" (Løvlie and Standish 2002, p. 319) and it is interesting to note that the same type of interactions between personal and societal values are also discussed in other related research areas such as Transformative Learning (Illeris 2014), Character and Citizenship Education (Sim and Ling Low 2012), and Environmental and Sustainability Education (Van Poeck and Vandenabeele 2012).

According to Henrik Bohlin (2008, p. 8), transformative learning theory, although only seldom explicitly associated with the idea of Bildung, "indicates ways to implement the ideal of moral Bildung in educational practice". Patricia Cranton (2011) discussed transformative learning and critical pedagogy in relation to an emancipatory scholarship of teaching and learning. From such a view "the assumptions, beliefs, norms and values of the discipline, the institution, the community and the state are directly and critically questioned" (p. 85) and such an approach "has the potential to yield a deep shift in perspective on teaching and learning at both an individual level and a social level". However, as claimed by Stephen Sterling (2011, p. 29), it is challenging to design "transformative educational experiences and learning systems [...] both in the immediate learning situation but also in the context of dominant educational paradigms and structures that essentially are not themselves transformed or sufficiently critically reflexive".

Because there is no precise English translation, the German term Bildung started to be used in the international educational literature (Westbury, Hopmann, and Riquarts 2000). During the last decade the concept has been problematized, mainly by postmodern theorists (Løvlie, Mortensen, and Nordenbo 2003; reviewed in Hansen 2008). Birgit Schaffar and Michael Uljens (2015) have identified the following two central points of criticism: (a) a logico-conceptual type of critique, where Bildung has been called a 'container word' and the meaning of emancipation has been questioned, and (b) a socio-cultural critique, whereby Bildung is reachable only for the elite and that it is thus "serving and solidifying the existing cultural power-structures" (p. 10).

However, some scholars-including me-claim that Bildung still works as a critical concept in a postmodern world (e.g. Biesta 2002). Ilan Gur-ze'ev (2002, p. 405) writes: "As counter-education, today's Bildung can contribute greatly to the reconstruction of [...] subjectification". According to Gert Biesta $(2012$, p. 7) a result of the process of subjectification is that the individuals become "autonomous-subjects of action and responsibility". This point "tries to capture a conception of human subjectivity that is not selfish or self-centred but always understood as being in responsible relation with other human beings and, by extension, with the natural world more generally" (Biesta 2013, 
p. 739). Instead of truth, Bildung is about cultural respect and socio-political justice (Peukert 2002). It can show us moral-philosophical-existential-political alternatives (Gurze'ev 2002).

Today at least five versions of Bildung are well-established (Burman 2011) and all of them have transformed over time from a mainly North European to a global focus (Gustavsson 2014). The five versions can be called: (a) von Humboldt's classical Bildung, (b) Anglo-American "liberal education", (c) Scandinavian folk-Bildung, (d) democratic education, and (e) critical-reflexive Bildung (Sjöström and Eilks 2017). It is mainly the latter version that is trying to adapt to the postmodern critique, and which $\mathrm{I}$ in the next section-in the light of worldviews (including eco-views)-will compare with Confucianism.

\section{Eco-views and eco-identities}

Just like Ulrich Beck (1992), I understand the contemporary society as a risk society, characterised by increasing complexity and unpredictable consequences of techno-scientific innovations and production. Therefore the society needs educated citizens who are able to understand the world and to make informed decisions - in both their private and professional lives, and as citizens engaged in democratic processes (Elmose and Roth 2005). Mogensen and Karsten Schnack (2010, p. 60) argue that "action competence is closely linked to democratic, political education and to [...] the notion of 'Bildung'". For Klafki, Bildung "involves competences for self-determination, constructive participation in society, and solidarity towards persons limited in the competence of self-determination and participation" (Elmose and Roth 2005, p. 21). Based on Klafki, the Danish educational philosopher Peter Kemp (2005; in English 2010) has discussed cosmopolitan ideals for global citizens in the 21 st century.

However, much in contrast to such thoughts, the developments within the Education for Sustainable Development (ESD) movement can be mainly characterized by a view of ecological modernization of society (e.g. Kopnina 2014). This ideology is characterized by instrumental rationality: (a) nature as a material resource to be exploited, and (b) belief in techno-scientific progress to find environmental solutions (Bader and Laberge 2014). It "results in overvaluing the technological expertise [...] at the expense of political analysis, ethical and/or cultural values" (Bader and Laberge 2014, p. 425). According to Savelyeva (2016, p. 14 a.o.p.) the dominant Western sustainability discourse is "grounded on the anthropocentric conception of the human-nature relationship, where nature needs to be properly managed within the three pillars of sustainability: economy, society, and the environment". It is about producing a sustainable person. However, alternative Westernand less anthropocentric - sustainability discourses have been suggested, such as a virtue ethics approach (Jordan and Kristjánsson 2016), self-reflective subjectivity (Straume 2015), transformative sustainability learning (e.g. Barrett, Harmin, Maracle, Patterson, Thomson, Flowers, and Bors 2017) and, as already mentioned, reflexive Bildung (Sjöström, Eilks and Zuin 2016).

Similarly, according to Kato (2016, p. 33) "the Confucian humanistic tradition not only corroborates the humanistic education of the West, but can modify its course in a direction that is less 'anthropocentric' and therefore more humane and human". In other words also Neo-Confucianism can be seen as an alternative to the dominant Western sustainability discourse (Savelyeva 2016). Yulgok, who is called 'the father of the East' and is the most 
renowned Korean Neo-Confucian scholar, positioned humans in harmony with cosmos. It should be achieved through individual self-cultivation. Yulgok's view can be called cosmoanthropic: "everything in the universe, including humans, shares life and deserves greatest respect [...] cosmos is not an object, physical reality, or a mechanical entity; cosmos is a dynamic and ever changing interpretive reality, which reflects human understanding, sense-making and interpretation of the universe" (Savelyeva 2016, p. 11-12 a.o.p.). From Yolgok's cosmoanthropic view a major educational objective is to "foster a holistic worldview and embed a set of values that allow a harmonious growth of self and society within a larger universe" (Savelyeva 2016, p. 14 a.o.p.).

Another more recent Korean philosophy, highly influenced by Neo-Confucianism, but also based on e.g. Taoism and Buddhism, is called Donghak (=Eastern learning). Seungho Moon (2016, p. 12 a.o.p.) writes: "the interconnection and equal relations among Godhuman-nature-cosmos in Donghak go beyond the anthropocentric understanding of humannature relation". Donghak can be seen as an alternative to dominant market-oriented educational reforms and has attracted supporters of an eco-centered curriculum (Moon 2016). Similarly, Chia-Ling Wang (2016) recently discussed Taoism and Buddhism in relation to the concepts of self-realisation and the ecological self according to 'ecosophy', and their implications on contemporary instrumental education. 'Ecosophy', developed by the Norwegian philosopher Arne Naess, is strongly influenced by the Buddhist tradition (Glasser 2011). Wang (2016, p. 1257) explains it with "a lifestyle incorporating ecological harmony or ecological wisdom".

With many similarities to the Eastern thoughts of co-living, and just like 'ecosophy' in a Western context, I together with colleagues recently discussed what we call eco-reflexive Bildung (Sjöström, Eilks and Zuin 2016). It adds an eco-dimension to critical-reflexive Bildung and takes a problematizing stance towards the modern risk society, globalization, neoliberalism, oppressive contexts, and anthropocentrism. With similarities to Yolgok's cosmoanthropic view and Donghak it views life and society as interdependent, an inseparable whole. We wrote:

The term eco-reflexive is used for a problematizing stance towards the modern risk society, an understanding of the complexity of life and society and their interactions, and a responsibility for individual and collective actions towards socio-ecojustice and global sustainability (Sjöström, Eilks and Zuin 2016, p. 321).

To sum up the discussion above one can say that ESD and ecological modernization is based on the ideas of Western modernism. On the other hand both Neo-Confucianism and eco-reflexive Bildung can be seen as less anthropocentric eco-ideas on which eco-identities can be based. In the following sections I will discuss different Western educational philosophies and visions of science education and how they relate to different curriculum approaches. As I will show below both reflexive Bildung and many Eastern philosophies integrate cognitive and affective domains.

\section{Science teachers' educational philosophies and different visions of scientific literacy}

There are in the West (read Anglo-American literature) four major contemporary educational philosophies. These are called essentialism, perennialism, progressivism, and reconstructionism (Ornstein 1991). Essentialism focuses on disciplinary knowledge, 
perennialism on cultural history, progressivism on the formation of the student, and reconstructionism on the transformation of society through critical citizenship. Sometimes reconstructionism is considered synonymous with critical pedagogy. Critical-reflexive Bildung is mainly oriented towards reconstructionism. The other four previously mentioned versions of Bildung are mainly oriented towards the other contemporary educational philosophies. For example Scandinavian folk-Bildung, democratic education, and also modern forms of liberal education are mainly oriented towards progressivism. They are highly influenced by Western modernism, whereas critical-reflexive Bildung is more influenced by late/post-modern perspectives.

When describing the development of philosophy of science education, David Blades (2008) identified three philosophical traditions since the 1970s and after the rationalistobjectivist focus during the 1960s: (a) science education for enlightenment, (b) science education for citizenship, and (c) science education for reconstruction. The phases can also be described as essentialism during 1960s, followed by (a) liberal education-perspectives (but still modernism), (b) late-modernism, and (c) postmodernism. In practice, I would claim that the rationalist-objectivist focus is still common in much science teaching around the globe. It is typically characterized by a predominantly transmissive view focused on content learning and the structure of the discipline (Eilks, Rauch, Ralle, and Hofstein 2013). In the science education literature it has been quite rare with publications that thoroughly discuss science education in relation to critical pedagogy and/or transformative learning (one exception is: Carter, Rodriguez, and Jones 2014).

One can ask if identity development/transformation is a bigger challenge in a Confucian learning culture with much respect for traditional values, than it is in Western cultures. It is possible, but at the same time there is probably a strong support for the traditional (rationalist-objectivist focus) way of teaching science, which seem to be at the core of many science teachers' professional identities, independent on the national culture. So the question is how much of science teacher identity and resistance to "new pedagogy" can be explained by the Confucian culture and how much is better explained with traditional, lecture-based, science education more generally? The ideas of the teacher as an expert focusing on the learning of facts and the goal to succeed on assessments and its connection to good carrier opportunities seem not to be specific for East Asia, even though it maybe is more pronounced there.

In line with this, a decade ago Glen Aikenhead (2006) contrasted a traditional discipline-oriented view of science education, based on an ideology of preprofessional training of elite students, with science education for all, including humanistic perspectives. He wrote: "I find humanistic the best word to describe the diverse yet pervasive alternative to the pipeline ideology of traditional school science" (p. 2). Aikenhead emphasised that humanistic perspectives in the science curriculum may be referred to with expressions such as STSE (science-technology-society-environment), socio-scientific issues (SSI), citizen science, and Bildung. These humanistic science perspectives have in common the goal of scientific literacy for all.

A year later Douglas Roberts (2007) distinguished between two main orientations of scientific literacy: Vision I, which focuses mainly learning about scientific content and scientific processes for later application, and Vision II, which focuses understanding the usefulness of scientific knowledge in life and society by starting science learning from meaningful contexts. Roberts (2011, p. 14) connects four (of seven) curriculum emphasizes (solid foundation; structure of science; correct explanations; scientific skill development) to Vision I and the other three (self as explainer; everyday coping; science, technology, and 
decisions) to Vision II. However, both Vision I and II can be said to be based on Western modernism.

As an alternative, together with Ingo Eilks, I recently suggested a Vision III of scientific literacy, based on the thoughts of reflexive Bildung (Sjöström and Eilks 2017). It asks for reconsidering both the contents and contexts of science education. Controversial, relevant, and authentic socio-scientific issues, e.g. from the sustainability debate, should according to a Vision III-perspective become the drivers for the curriculum. Such an orientation has also been called issues-based STSE education (Pedretti, Bencze, Hewitt, Romkey, and Jivraj 2008). It challenges traditional images of science education and traditional science teachers' professional identities. Compared to the phases in the development of philosophy of science education, Vision $I$ can be seen as corresponding to essentialism and a rationalist-objectivist focus, Vision II to utility-perspectives, and Vision III to late/postmodern perspectives.

In line with Vision III, Pedretti, Bencze, Hewitt, Romkey, and Jivraj (2008, p. 955) described their 'post-positivist vision' of science education with the following key-words: interdisciplinary; uncertainty; multiple solutions; the coupling of science and ethics; decision-making; socio-political action; teacher as facilitator and guide, and transformation. In addition to these characteristics for example Nancy Brickhouse (2001) has emphasized the importance of an embodied science education, which overcomes the bodymind dualism, and I together with colleagues have discussed a science education that overcomes the culture-nature dualism (Sjöström, Eilks and Zuin 2016).

\section{Effects on the praxis of science education}

Science teacher identity can be expected to be one important factor in the choice of curriculum approach. Eilks, Rauch, Ralle, and Hofstein (2013) have described a range of curriculum approaches in chemistry education from fundamental (disciplinary-oriented), via context-based and CTS (Chemistry-Technology-Society), towards SSI and sustainability driven curricula. Similarly, Erminia Pedretti and Joanne Nazir (2011) have discussed different orientations of STSE education-from application-oriented to sociocultural-oriented to socio-ecojustice-oriented.

Jean Simonneaux and Laurence Simonneaux (2012) have described what they call different educational configurations within science education (especially for environmental socio-scientific issues). An educational configuration consists of teachers' epistemological postures (scientism, utilitarianism, skepticism, or relativism), various conceptions of knowledge (universal, plural, engaged, or contextualized), and various didactical strategies (doctrinal, problematizing, critical, or pragmatic). They describe four mixtures of these, which they called archetypical educational configurations:

- Hierarchical configuration (scientism; universal knowledge; doctrinal).

- Professional configuration (utilitarianism; contextualized knowledge; pragmatic).

- Problematizing configuration (skepticism; plural knowledge; problematizing).

- Critical configuration (skepticism; engaged knowledge; critical).

There are similarities between hierarchical configuration and essentialism, between professional configuration and progressivism, and between problematizing/critical configurations and reconstructionism. Consequently, there are also similarities to the three visions of scientific literacy/science education: 
- Vision I: essentialism; rationalist-objectivist focus; scientism; hierarchical configuration.

- Vision II: progressivism; pragmatic; Western modernism; economic concerns; anthropocentrism; body-mind dualism; utilitarianism; liberal education-perspectives; professional configuration.

- Vision III: reconstructionism; late/post-modern perspectives; post-positivism; embodied science; relationalism; skepticism; moral-philosophical-existential-political alternatives; biocentrism; eco-reflexivity; problematizing/critical configurations; socio-ecojustice-oriented STSE-perspectives.

Below I relate these visions to some previous studies focusing on different science teacher identities and related curriculum approaches. Pedretti, Bencze, Hewitt, Romkey, and Jivraj (2008) have discussed different tensions and dilemmas for new science teachers when implementing STSE perspectives in their teaching. They discussed it in relation to identity and ideology. The tensions are related to: control and autonomy; support and belonging; expertise and negotiating curriculum; politicization and action; and biases and ideological bents. They wrote: "an STSE orientation presents a particular image of science teaching and a particular set of pedagogical challenges that are different from 'normal' patterns of practice" (p. 955). Tom Bryce (2010) has in this journal discussed the resistance to humanistic science education in practice. He contrasted the dominant Science-for-scientists view (emphasising content) with Science-for-citizenship (emphasising contextual complexities). Similarly, Per Sund (2016) recently discussed, also in this journal and based on an empirical study, different selective traditions in science education. He argued for three orientations with some similarities to the three visions described above. The first tradition is disciplinary oriented, the second one oriented towards applications, and the third one towards societal issues. However, the latter is better described with 'Vision IIB' (as Sund also does in his paper) rather than with Vision III.

But in line with Vision III-thinking Paul Hart (2012) focused on the need to change the discourses in science teaching, rather than changing the students. He claimed that traditional science education is based on a rationalist-objectivist foundation and that "serious consideration of how people learn implies changes [...] to one that engages a range of personal sociocultural and political issues within a frame of multiple ways of knowing" (p. 104). In a way the tension can be understood as a conflict between modernism (including scientism) and postmodernism in science education (Blades 2008). It also mirrors a tension between views in traditional (rationalist-objectivist) science education versus common views in the area of Environmental and Sustainability Education (Dillon 2014). The latter focusses much more on interactive relational production of knowledge. Laura ColucciGray and Elena Camino (2014) express it as 'science of relationships' and 'epistemic and reflexive knowledge'.

As described above there are several different orientations of Eastern philosophies and some of them (e.g. Neo-Confucianism) have similarities to reflexive Bildung and Vision III. In line with these ideas, Michael Littledyke (2008) has argued for integrating cognitive and affective domains in science education. For example he suggested to include politicisation to address socio-scientific and environmental issues. In an illustrative figure he described the differences between modern/traditional science and postmodern science, and also its educational implications. According to him modern/traditional science is characterised by a stereotypical separation between cognitive and affective domains and it can be described with labels such as objectivism, reductionism-mechanistic and value-free. The corresponding pedagogy is described by him with labels such as transmission, non-contextual 
and facts-based. Instead he suggested a 'constructive postmodern science', which is characterised by integration between cognitive and affective domains, critically informed views of issues, systems thinking and uncertainty. The corresponding pedagogy Littledyke described with labels such as active learning, interdisciplinary approach and real-life contexts.

As a result of this article we have gain a multifaceted understanding of Vision III-driven science education. It is not possible to summarize it in just a few words (although I tried above), but one can say that it is an alternative to science education based on Western modernism. It integrates cognitive and affective domains and includes politicisation to address complex socio-scientific and environmental issues. Relations and responsibility are emphasized.

\section{Implications for science teacher education and professional development programs}

With a reflexive Bildung-approach to science education, the professional identity of the science teacher is as much that of a 'meta-scientist' as it is of a 'scientist' (Sjöström 2013). Already more than a decade ago Aikenhead (2003, p. 125) wrote: "One major challenge for chemistry and physics teachers is to rethink and reformulate their professional identities away from being loyal and accountable to their discipline". What then would characterise science teacher education and professional development programs that emphasize ecoreflexive science? Two main perspectives that would complement the content focus in dominant science education are 'science as culture' and 'science within culture'. Ecoreflexive-oriented science education is about problematisation, understanding uncertainties, and balancing the benefits and risks of science and technology; it deals with ethical and societal aspects in the teaching. With this type of science education, science teachers in addition to deep knowledge in science - also need extensive knowledge about science and technology (meta-perspectives), including educational perspectives. The Bildung-and/ or Neo-Confucian-oriented science teacher has a reflexive approach.

In their article Huang and Asghar discuss implications for professional development programs: "Teachers should be supported in professional development programs to critically reflect on their teaching philosophies, personal values and professional goals in relation to the reform objectives" (p. 12 a.o.p.). As argued in this forum article the teachers' cultural values, ideologies, worldviews, eco-views etc. and educational philosophies are crucial for both their identity and curriculum approaches, and accordingly praxis. Therefore such perspectives should be highlighted in both science teacher educations and professional development programs and discussed in relation to transformation of educational practice.

Both reflexive Bildung and Neo-Confucianism can, in Reichenbach's (2016, p. 37) words, be viewed as philosophies of "self-transformation which offers a great opportunity for critical reflections on today's rather superficial and instrumental understanding of learning". They both support eco-transformation of education, life and society.

Open Access This article is distributed under the terms of the Creative Commons Attribution 4.0 International License (http://creativecommons.org/licenses/by/4.0/), which permits unrestricted use, distribution, and reproduction in any medium, provided you give appropriate credit to the original author(s) and the source, provide a link to the Creative Commons license, and indicate if changes were made. 


\section{References}

Aikenhead, G. (2003). Chemistry and physics instruction: Integration, ideologies, and choices. Chemistry Education Research and Practice, 4, 115-130.

Aikenhead, G. S. (2006). Science education for everyday life: Evidence-based practice. New York: Teachers College Press.

Avraamidou, L. (2014). Studying science teacher identity: Current insights and future research directions. Studies in Science Education, 50, 145-179.

Bader, B., \& Laberge, Y. (2014). Activism in science and environmental education: Renewing conceptions about science among students when considering socioscientific issues. In L. Bencze \& S. Alsop (Eds.), Activist science and technology education (pp. 419-433). Dordrecht: Springer.

Barrett, M. J., Harmin, M., Maracle, B., Patterson, M., Thomson, C., Flowers, M., \& Bors, K. (2017). Shifting relations with the more-than-human: Six threshold concepts for transformative sustainability learning. Environmental Education Research, 23, 131-143. doi:10.1080/13504622.2015.1121378.

Beck, U. (1992). Risk society: Towards a new modernity. London: Sage.

Bernstein, R. J. (1983). Beyond objectivism and relativism: Science, hermeneutics, and praxis. Philadelphia: University of Pennsylvania Press.

Biesta, G. (2002). How general can Bildung be? Reflections on the future of a modern educational ideal. Journal of Philosophy of Education, 36, 377-390.

Biesta, G. (2012). Have lifelong learning and emancipation still something to say to each other? Studies in the Education of Adults, 44, 5-20.

Biesta, G. (2013). Responsive or responsible? Democratic education for the global networked society. Policy Futures in Education, 11, 733-744.

Blades, D. (2008). Positive growth: Developments in the philosophy of science education. Curriculum Inquiry, 38, 387-399.

Bohlin, H. (2008). Bildung and moral self-cultivation in higher education: What does it mean and how can it be achieved? Forum on Public Policy Online, no 2/2008, Retrieved May 19, 2016 from forumonpublicpolicy.com/summer08papers/archivesummer08/bohlin.pdf.

Brickhouse, N. W. (2001). Embodying science: A feminist perspective on learning. Journal of Research in Science Teaching, 38, 282-295.

Bryce, T. G. K. (2010). Sardonic science? The resistance to more humanistic forms of education. Cultural Studies of Science Education, 5, 591-612.

Burman, A. (2011). Svar på frågan: Vad är medborgerlig bildning? [Answer on the question: What is civicBildung?]. In A. Burman (Ed.), Våga veta! Om bildningens möjligheter i massutbildningens tidevarv (pp. 9-31). Huddinge: Södertörns högskola.

Carter, L., Rodriguez, C. C., \& Jones, M. (2014). Transformative learning in science education: Investigating pedagogy for action. In L. Bencze \& S. Alsop (Eds.), Activist science and technology education (pp. 531-545). Dordrecht: Springer.

Colucci-Gray, L., \& Camino, E. (2014). From knowledge to action? Re-embedding science learning within the planet's web. In L. Bencze \& S. Alsop (Eds.), Activist science and technology education (pp. 149164). Dordrecht: Springer.

Cranton, P. (2011). A transformative perspective on the scholarship of teaching and learning. Higher Education Research and Development, 30, 75-86.

Dillon, J. (2014). Environmental education. In N. G. Lederman \& S. K. Abell (Eds.), Handbook of research on science education (2nd ed., pp. 497-514). New York: Routledge.

Dupré, J. (2001). Human nature and the limits of science. Oxford: Clarendon Press.

Eilks, I., Rauch, F., Ralle, B., \& Hofstein, A. (2013). How to allocate the chemistry curriculum between science and society. In I. Eilks \& A. Hofstein (Eds.), Teaching chemistry-A studybook (pp. 1-36). Rotterdam: Sense Publishers.

Elmose, S., \& Roth, W.-M. (2005). Allgemeinbildung: readiness for living in risk society. Journal of Curriculum Studies, 37, 11-34.

Fellenz, M. R. (2016). Forming the professional self: Bildung and the ontological perspective on professional education and development. Educational Philosophy and Theory, 48, 267-283.

Fischler, H. (2011). Didaktik-An appropriate framework for the professional work of science teachers? In D. Corrigan, J. Dillon, \& R. Gunstone (Eds.), The professional knowledge base of science teaching (pp. 31-50). Dordrecht: Springer.

Fischler, H. (2015). Bildung. In R. Gunstone (Ed.), Encyclopedia of science education (pp. 118-122). Dordrecht: Springer.

Glasser, H. (2011). Naess's deep ecology: Implications for the human prospect and challenges for the future. Inquiry, 54, 52-77. 
Gur-ze'ev, I. (2002). Bildung and critical theory in the face of postmodern education. Journal of Philosophy of Education, 36, 391-408.

Gustavsson, B. (2014). Bildung and the road from a classical into a global and postcolonial concept. Confero: Essays on Education, Philosophy and Politics, 2, 109-131.

Hansen, K.-H. (2008). Rewriting Bildung for postmodernity: Books on educational philosophy, classroom practice, and reflective teaching. Curriculum Inquiry, 38, 93-115.

Haraway, D. J. (1989). Primate visions: Gender, race, and nature in the world of modern science. New York: Routledge.

Hart, P. (2012). Creating spaces for rethinking school science: Perspectives from subjective and socialrelational ways of knowing. In A. Zeyer \& R. Kyburz-Graber (Eds.), Science | Environment | Health: Towards a renewed pedagogy for science education (pp. 103-125). Dordrecht: Springer.

Huang, Y.-S., \& Asghar, A. (this issue). Science education reform in Confucian learning cultures: Teachers' perspectives on policy and practice in Taiwan. Cultural Studies of Science Education, advance article. doi:10.1007/s11422-016-9762-4.

Hung, R. (2016). A critique of Confucian learning: On learners and knowledge. Educational Philosophy and Theory, 48, 85-96.

Hwang, K. (2013). Educational modes of thinking in Neo-Confucianism: A traditional lens for rethinking modern education. Asia Pacific Education Review, 14, 243-253.

Illeris, K. (2014). Transformative learning and identity. Journal of Transformative Education, 12, 148-163.

Jordan, K., \& Kristjánsson, K. (2016). Sustainability, virtue ethics, and the virtue of harmony with nature. Environmental Education Research, advance article. doi:10.1080/13504622.2016.1157681.

Kato, M. (2016). Humanistic traditions, East and West: Convergence and divergence. Educational Philosophy and Theory, 48, 23-35.

Kemp, P. (2005; in English 2010). Världsmedborgaren: Politisk och pedagogisk filosofi för det 21 århundradet [Citizen of the World: Cosmopolitan Ideals for the $21^{\text {st }}$ Century]. Göteborg: Daidalos (in Swedish).

Klafki, W. (2000). The significance of classical theories of Bildung for a contemporary concept of Allgemeinbildung. In I. Westbury, S. Hopmann, \& K. Riquarts (Eds.), Teaching as a reflective practice: The German Didaktik tradition (pp. 85-108). Mahwah: Lawrence Erlbaum.

Kopnina, H. (2014). Future scenarios and environmental education. The Journal of Environmental Education, 45, 217-231.

Kwak, D. J., Kato, M., \& Hung, R. (2016). The Confucian concept of learning revisited for East Asian humanistic pedagogies. Educational Philosophy and Theory, 48, 1-6.

Liedman, S.-E. (1997). I skuggan av framtiden - Modernitetens idéhistoria [In the shadow of the futureHistory of modernity]. Albert Bonniers Förlag.

Littledyke, M. (2008). Science education for environmental awareness: Approaches to integrating cognitive and affective domains. Environmental Education Research, 14, 1-17.

Løvlie, L., Mortensen, K. P., \& Nordenbo, S. E. (Eds.) (2003). Educating humanity - Bildung in postmodernity. Malden, MA: Blackwell Publishing (first published in 2002 as volume 36, issue 3 of the Journal of Philosophy of Education).

Løvlie, L., \& Standish, P. (2002). Introduction: Bildung and the idea of a liberal education. Journal of Philosophy of Education, 36, 317-340.

Luehmann, A. L. (2007). Identity development as a lens to science teacher preparation. Science Education, 91, 822-839.

Mogensen, F., \& Schnack, K. (2010). The action competence approach and the 'new' discourses of education for sustainable development, competence and quality criteria. Environmental Education Research, 16, 59-74.

Moon, S. (2016). Donghak (Eastern learning), self-cultivation, and social transformation: Towards diverse curriculum discourses on equity and justice. Educational Philosophy and Theory, advanced article. doi:10.1080/00131857.2016.1216386.

Ornstein, A. C. (1991). Philosophy as basis for curriculum decisions. The High School Journal, 74, 102-109.

Pedretti, E., Bencze, L., Hewitt, J., Romkey, L., \& Jivraj, A. (2008). Promoting issues-based STSE perspectives in science teacher education: Problems of identity and ideology. Science \& Education, 17, 941-960.

Pedretti, E., \& Nazir, J. (2011). Currents in STSE education: Mapping a complex field, 40 years on. Science Education, 95, 601-626.

Peukert, H. (2002). Beyond the present state of affairs: Bildung and the search for orientation in rapidly transforming societies. Journal of Philosophy of Education, 36, 421-435.

Reichenbach, R. (2014). Humanistic Bildung: Regulative idea or empty concept? Asia Pacific Education Review, 15, 65-70. 
Reichenbach, R. (2016). “The source of learning is thought” reading the Chin-ssu lu (近思錄) with a "Western Eye". Educational Philosophy and Theory, 48, 36-51.

Rivera Maulucci, M. S. (2013). Emotions and positional identity in becoming a social justice science teacher: Nicole's story. Journal of Research in Science Teaching, 50, 453-478.

Roberts, D. A. (2007). Scientific literacy/science literacy. In S. K. Abell \& N. G. Lederman (Eds.), Handbook of research on science education (pp. 729-780). Mahwah: Lawrence Erlbaum.

Roberts, D. A. (2011). Competing visions of scientific literacy: The influence of a science curriculum policy image. In C. Linder, L. Östman, D. A. Roberts, P.-O. Wickman, G. Erickson, \& A. MacKinnon (Eds.), Exploring the landscape of scientific literacy (pp. 11-27). London: Routledge.

Saka, Y., Southerland, S. A., Kittleson, J., \& Hutner, T. (2013). Understanding the induction of a science teacher: The interaction of identity and context. Research in Science Education, 43, 1221-1244.

Savelyeva, T. (2016). Vernadsky meets Yulgok: A non-Western dialog on sustainability. Educational Philosophy and Theory, advanced article. doi:10.1080/00131857.2016.1138851.

Schaffar, B., \& Uljens, M. (2015). Paradoxical tensions between Bildung and Ausbildung in academia: Moving within or beyond the modern continental tradition. In E. Westergaard \& J. S. Wiewiura (Eds.), On the facilitation of the academy (pp. 1-15). Rotterdam: Sense.

Sim, J. B. Y., \& Ling Low, E. (2012). Character and citizenship education: Conversations between personal and societal values. Asia Pacific Journal of Education, 32, 381-394.

Simonneaux, J., \& Simonneaux, L. (2012). Educational configurations for teaching environmental socioscientific issues within the perspective of sustainability. Research in Science Education, 42, 75-94.

Sjöström, J. (2006). Lärarskapet i högskolan bör vara bildningsorienterat [The scholarship of teaching and learning should be Bildung-oriented]. Nyheter \& Debatt, no. 5/2006, p. 5 (in Swedish).

Sjöström, J. (2007). The discourse of chemistry (and beyond). HYLE-International Journal for Philosophy of Chemistry, 13, 83-97.

Sjöström, J. (2013). Towards Bildung-oriented chemistry education. Science \& Education, 22, 1873-1890.

Sjöström, J., \& Eilks, I. (2017). Reconsidering different visions of scientific literacy and science education based on the concept of Bildung. In J. Dori, Z. Mevarech, \& D. Baker (Eds.), Cognition, metacognition, and culture in STEM education. Dordrecht: Springer.

Sjöström, J., Eilks, I., \& Zuin, V. (2016). Towards eco-reflexive science education. Science \& Education, 25 , 321-341.

Sterling, S. (2011). Transformative learning and sustainability: Sketching the conceptual ground. Learning and Teaching in Higher Education, 5, 17-33.

Straume, I. S. (2015). The subject and the world: Educational challenges. Educational Philosophy and Theory, 47, 1465-1476.

Sund, P. (2016). Discerning selective traditions in science education: A qualitative study of teachers' responses to what is important in science teaching. Cultural Studies of Science Education, 11, 387-409.

Tan, L. (2016). Confucius: Philosopher of twenty-first century skills. Educational Philosophy and Theory, $48,1233-1243$.

Van Poeck, K., \& Vandenabeele, J. (2012). Learning from sustainable development: Education in the light of public issues. Environmental Education Research, 18, 541-552.

Von Wright, G. H. (1978). Humanismen som livshållning [Humanism as a life stance]. Stockholm: $\mathrm{AB}$ Rabén \& Sjögren Bokförlag.

Wang, C.-L. (2016). Towards self-realisation: Exploring the ecological self for education. Educational Philosophy and Theory, 48, 1256-1265.

Westbury, I., Hopmann, S., \& Riquarts, K. (Eds.). (2000). Teaching as a reflective practice: The German Didaktik tradition. Mahwah: Lawrence Erlbaum.

Jesper Sjöström is an Associate Professor of Science Education in the Faculty of Education and Society at Malmö University, Sweden. Prior to joining Malmö University he did postdoctoral research at the Research Policy Institute, Lund University. His current research focuses on science education for citizenship and sustainability. He has particular interests in the praxis implications of different educational philosophies and in socio-scientific issues concerning health and environment. 